\title{
O PAPEL DO STF NA CONCEPÇÃO DISTORCIDA DO DOMÍNIO DO FATO. COMO A AÇÃO PENAL 470 INAUGUROU UM ENTENDIMENTO EQUIVOCADO DA TEORIA NA DOUTRINA E JURISPRUDÊNCIA BRASILEIRAS
}

\author{
THE ROLE PLAYED BY THE BRAZILIAN SUPREME COURT IN THE MISCONCEPTION OF THE \\ CONTROL OVER THE ACTION THEORY
}

Marcela Oliveira Silva*

\begin{abstract}
Resumo:
Este artigo pretende analisar o julgamento da Ação Penal 470, sob a perspectiva de qual o entendimento apresentado pelos ministros do Supremo Tribunal Federal a respeito da teoria do domínio do fato. Nosso objetivo não é fazer um exame dos fatos, tampouco dos resultados a que chegaram os ministros, e sim procurar buscar qual a perspectiva sustentada pelos ministros sobre o domínio do fato. Para isso, introduziremos breves considerações a respeito da teoria e, sem seguida, seguiremos para análise do acórdão.

Palavras-chave: Ação Penal 470. Mensalão. Roxin. Domínio do fato.

Abstract:

This paper aims to analyze the court ruling issued by the Brazilian Supreme Court in the Criminal Lawsuit 470, under the perspective of how the judges understood the Control Theory of Perpetration. Our goal is not to exam the fact nor the results reached by the judges, but rather to pursue the understanding of the arguments sustained by the Court regarding the control of perpetration. For this purpose, we will introduce some considerations about the doctrine, followed by the study of the court ruling.
\end{abstract}

Keywords: Criminal Lawsuit 470. Mensalão. Roxin. Control Theory of Perpetration.

\section{Introdução}

Este artigo se destina a examinar como o Supremo Tribunal Federal concebeu a teoria do domínio do fato, desenvolvida por Claus Roxin. A AP 470/MG foi paradigmática na determinação de jurisprudência a respeito dessa teoria, o que torna sua análise essencial: o entendimento suscitado pelo STF neste caso instituiu uma jurisprudência problemática que enseja aplicações equivocadas da teoria e um desvirtuamento do trabalho de Roxin.

Bacharela em Direito pela Faculdade de Direito da Universidade de São Paulo (FDUSP). Mestranda na FDUSP, no Departamento de Direito Internacional e Comparado. Este artigo foi originalmente desenvolvido como parte do Trabalho de Conclusão do Curso de Graduação. 
Tal inovação jurisprudencial é especialmente preocupante em vista dos diversos novos casos, notadamente de corrupção e crimes empresariais, levados ao STF e outras cortes nacionais. Os novos julgados terão o arcabouço teórico como apreciado pelo Supremo para se espelharem, potencialmente replicando o mau entendimento do domínio do fato.

\section{Considerações teóricas}

A antiga visão causal-naturalista partia da premissa da mera observação da causalidade, admitindo que qualquer pessoa que contribuísse para dar causa aos eventos seria igualada ao status de autor. Superando esta vertente, o enfoque passou a ser a finalidade dos comportamentos, inaugurando uma perspectiva teleológico-normativa, de acordo com a qual as regulações e valores jurídicos não são deduzidos da realidade, sim produzidos pela valoração humana com base na ideia de finalidade.

Roxin analisa os métodos normativo e ontológico para concluir que a ponderação sobre autoria e participação depende de uma síntese entre esses dois métodos. Para começar, a matéria objeto de regulação jurídica não é definida pelo legislador, mas captada da realidade. Não obstante, é o legislador que irá escolher o que, destas estruturas, será efetivamente objeto de regulamentação. Nesse sentido, a definição de autoria pode começar numa realidade ontológica, mas acaba em valoração pelo legislador segundo critérios valorativos específicos.

Em suma, Roxin é da posição de que essas duas linhas metodológicas são complementares entre si, pois cada uma delas, isoladamente, pode levar à indeterminação conceitual: se o método ontológico pode não dar conta de situações mais complexas (como autoria mediata), o método normativo abre margem a conceito indeterminados que não têm um referencial na observação social. Em outras palavras, a construção ontológica contribui no estabelecimento sólido do conceito por meio de devidos referenciais nas estruturas prévias ontológicas, enquanto o método normativo, por meio de critérios valorativos adequados, dá conta de distinguir situações complexas, cuja mera constatação social não capta suficientemente.

No existe aquí $[\ldots]$ una imbricación estructural de ser y deber en el sentido de que el ser exento de valoración y las ideas finalistas de los sujetos empíricos se vincularan entre sí, pero tampoco ocurre que un ser prejurídico con contenido valorativo prefigure por sí solo los contenidos del ordenamiento jurídico; más bien los contenidos de significado previos y los establecimientos de valoración creadores de sentido se interpenetran de manera que se produce entre ellos una interacción continua y el resultado no se presenta como una estructura fija, sino como la 
resultante de un proceso, en evolución incesante, de influencia recíproca. (ROXIN, 2000, p. 44).

2.1. A conceituação da figura central de autor. Posicionamento sistemático do domínio do fato

O autor é a figura central do ato praticado e, portanto, o conceito primário na teoria do domínio do fato. A participação e a definição dos partícipes dependem da determinação da autoria, enquanto conceito secundário. Roxin segue então o esforço de como trabalhar o conceito da figura central do autor como conceito aberto.

A figura central do autor e o domínio do fato devem ser compreendidos como um conceito aberto, com o propósito de consolidar um entendimento que tanto dê conta de um nível de determinação conceitual como também das mais diversas situações concretas. $\mathrm{O}$ conceito aberto é caracterizado primeiro por procedimento descritivo, cuja vantagem é se amoldar ao sentido de diferentes casos.

A descrição mantém proximidade da realidade em vez de recorrer a uma total abstração. Somado a isso, a descrição não opera por fórmulas, de forma que nunca está concluída, possibilitando que possa vir a contemplar até mesmo estruturas ainda desconhecidas de participação e autoria.

Se a descrição pode sempre comportar novos elementos, para não regredir a um conceito indeterminado, são necessárias balizas para delimitar como esses elementos podem contemplar a situação fática. Tais balizas são os princípios regulativos, sobre as quais Roxin salienta que:

No existe peligro de retroceder al concepto indeterminado, pues cada ámbito vital a regular jurídicamente suele contener tantos elementos tipificables que ya su captación completa presta al concepto contornos precisos. Además, delimitando estrictamente el ámbito de aplicación del principio regulativo, una directriz permite una decisión bastante segura en este ámbito limitado incluso cuando la solución se hace depender de la consideración del caso concreto. (ROXIN, 2000, p. 148).

Feliciano (2006, p. 52) sintetiza essas características da definição da figura central do autor:

Antes, [a teoria do domínio do fato] remete a uma construção descritiva, baseada em elencos contextuais não-exaustivos. [...] Doutra feita, se por um lado a descrição delimita com precisão diversos casos típicos de intervenção de agentes múltiplos em uma mesma ação delitiva (permitindo, assim, a formulação de juízos genéricos), por outro não oferece uma 
solução generalizadora, cabendo-lhe, como conceito aberto, a função de subministrar ao julgador princípios reguladores que orientem, por indução, no vácuo dos modelos de conduta. Eis, pois, os dois elementos do conceito aberto, na preleção de Claus Roxin: o procedimento descritivo e os princípios reguladores informativos.

Compreendida a forma como Roxin define a figura central do autor, nos resta entender como se enquadra o critério do domínio do fato para determinar autoria e participação.

Para isso, precisamos antes ter em mente que as teorias até então desenvolvidas para delinear critérios de autoria e participação poderiam ser distinguidas entre o conceito extensivo do autor e o conceito restritivo de autor.

Pelo conceito extensivo, não se faz diferença entre as diversas atuações para distinguir autoria e participação. Todas as contribuições são igualadas no plano de autoria com base no nexo da causalidade, mas existem disposições especiais que definem o status diferencial de partícipe, as quais são causas de restrição da punibilidade. Já o conceito restritivo tem por consequência a teoria objetiva da autoria. Essa está subdividida em duas espécies: teoria objetivo-formal, pela qual é autor aquele que executa pessoalmente a ação típica; e teoria objetivo-material, que procura, através de critérios objetivos, definir qual a contribuição mais importante para realização do fato típico (CALLEGARI, 2001, p. 78-81).

Com efeito, Roxin (2000, p. 360) enquadra o domínio do fato como um conceito restritivo de autor, enquanto a participação contempla causas de extensão da pena. Ao incorporar tanto os aspectos subjetivos quanto objetivos da realização do tipo penal, o domínio do fato representou uma nova perspectiva para o conceito restritivo, por superar as limitações de serem apenas considerados ou elementos objetivos ou subjetivos para distinguir autoria e participação. Conforme explica Gómez Benítez (1984, p. 105), a adoção do conceito restritivo é importante ponto de partida para a adequada diferenciação entre autor e partícipe, uma vez que (i) supere uma incoerência da teoria extensiva ao forçar a responsabilizar como autor aquele que realiza pessoalmente o ato, independentemente de ter o fato como seu; e (ii) suscite inevitavelmente a necessidade de trabalhar com o conceito de domínio do fato, para dar conta de casos mais complexos como autoria mediata e coautoria. Damásio de Jesus (1999, p. 111) reforça esta posição, clamando pela necessidade do domínio do fato à resolução de casos concretos.

\subsection{Limites do domínio do fato}

Enquanto critério para apurar autoria, o domínio do fato não é instrumento suficiente para analisar todas as estruturas de autor. Roxin reconhece que há estruturas 
alheias ao domínio do fato, notadamente os delitos de dever. Tratam-se de delitos que trazem no tipo penal uma caracterização especial do que seja o autor do delito. Em outras palavras, a prática do curso causal destes delitos incorpora de tal forma a caracterização do sujeito que tal fato não pode ser dominado: o delito não pode ser controlado objetiva e subjetivamente por uma pessoa, mas sim está fundamentado em uma característica normativa ou pessoal de determinado sujeito.

Nos delitos de dever, o tipo penal incorpora um posicionamento normativo do autor. Em torno do autor, em decorrência muitas vezes de uma função que exerce socialmente ou de uma situação social em que o sujeito se coloca, são construídas expectativas sociais de proteção e garantia de determinado bem. Proteger e garantir este bem passa a ser a conduta exigível do sujeito enquanto um dever extrajurídico penal, de forma que o não cumprimento do dever implica na lesão a este bem e na prática do delito.

Portanto, somente o titular do dever pode ser considerado autor do delito. Para fins de nomenclatura, o titular do dever é chamado intraneus, enquanto aquele que venha a contribuir para o delito mas é externo ao âmbito do dever recebe a alcunha de extraneus. $\mathrm{O}$ extraneus, assim, nunca ocupará a posição de autor, mas apenas de partícipe.

\subsection{Categorias de domínio}

De forma sintetizada, o domínio do fato pode se manifestar segundo três categorias. A primeira estrutura de domínio do fato é o domínio da ação, no qual o autor é aquele que, sem ser coagido e independente de outro superior, realiza todos os atos, executando-os por si próprio.

A segunda, o domínio da vontade, o autor dominar por fazer predominar sua vontade, ela que vai reger o curso causal. Assim, o domínio da vontade contempla os casos de autoria mediata. Nessa esfera, o "sujeito de trás" que verdadeiramente o controla a vontade regente sobre o curso causal, pode manifestar este controle por diferentes modalidades, de forma que a autoria mediata comporta diferentes estruturas, como coação e aparatos organizados de poder.

Esta última merece destaque. Ela pressupõe que o executor é indiferente e todos os recursos para realização do fato estão à disposição do sujeito de trás. Portanto, o elemento essencial é a fungibilidade do executor. Mas não podemos pensar que o executor estará isento de responsabilização, pois na verdade ainda terá de responder pelo ato cometido de forma direta. O que ocorre é que isso não interfere na apuração da autoria mediata do homem de trás.

Tal configuração se apresenta e apenas se manifesta em duas formas: (i) quando se trata do próprio poder estatal, não vigentes as garantias de um Estado 
democrático de direito; e (ii) organizações criminosas e clandestinas, que operam à margem do direito vigente.

\begin{abstract}
Así, cuando en un Estado de Derecho una autoridad determina a sus subordinados a cometer delitos o cuando en las Fuerzas Armadas un mando imparte órdenes antijurídicas, ello ha de valorarse siempre, salvo que haya que afirmar la autoría por otras razones, sólo como inducción, pues si todo el aparato se mueve por los cauces del Derecho, "funciona" de la manera requerida por la estructura de dominio descrita únicamente al utilizar las vías preestablecidas por el ordenamiento jurídico. Una instrucción antijurídica no puede poner aquí la organización en movimiento; si es obedecida, no se trata de una acción de la maquinaria de poder, sino de una "iniciativa particular" llevada a cabo eludiendo su modo de funcionar, cuya característica entonces suele ser también la ocultación cuidadosa con respecto a los demás titulares de competencias de la organización. Así, pues, en tales casos no se actúa con el aparato, sino contra él, quedando excluidos de entrada del ámbito del posible dominio de la organización. (ROXIN, 2000, p. 277).
\end{abstract}

Por fim, o domínio de fato funcional é baseado na coautoria, pela qual cada indivíduo do fato é globalmente considerado uma vez em cooperação com os demais, ou seja, ele não tem o domínio total do fato nem exerce um domínio parcial. O domínio é compartilhado por um grupo que apenas tem esse domínio enquanto grupo.

\title{
3. A Ação Penal 470
}

\subsection{Breve exposição dos fatos e estrutura do acórdão}

No curso do acórdão, os ministros votam o caso de forma fragmentada, acompanhando divisão estabelecida na denúncia em seis capítulos. Contudo, antes é preciso compreender que o esquema de corrupção foi dividido em três núcleos de operação.

O primeiro é chamado núcleo político, também considerado o núcleo central e capitaneado por José Dirceu, José Genuíno, Delúbio Soares e Sílvio Pereira. Supostamente, eles seriam os responsáveis por organizar uma quadrilha voltada à compra de apoio político entre os parlamentares.

Com o apoio da cúpula do governo, os integrantes do segundo núcleo, o publicitário, atuando como intermediários na compra de votos de membros do Congresso Nacional, deram início a operações de desvio de recursos públicos por meio de favorecimentos indevidamente obtidos em contratações públicas, além de lavagem de dinheiro para encobrir a origem dos recursos. O núcleo publicitário seria organizado pelos dirigentes de grandes empresas publicitárias, notadamente Marcos Valério, Ramon Hollerbach e Cristiano Paz. 
Por fim, o núcleo financeiro, contemplando dirigentes do Banco Rural, se valia de sua posição na instituição financeira para fornecer os valores necessários ao pleno funcionamento da operação, sob o pretexto de empréstimos, que eram ilicitamente concedidos a membros dos outros dois núcleos.

A análise considerará a votação iniciada pelo Ministro Joaquim Barbosa, a respeito do capítulo III. Neste capítulo, os réus Marco Valério, Ramon Hollerbach e Cristiano Paz são acusados de corrupção ativa, pelo pagamento de valores ao parlamentar João Paulo Cunha a fim de obter favores em contrato publicitário com a Câmara dos Deputados. Por este mesmo fato, João Paulo da Cunha enfrentou acusação de corrupção passiva e lavagem de dinheiro. Ainda sobre os contratos com a Câmara, os réus foram acusados de peculato, pelo desvio nas contratações.

No mesmo capítulo, os réus do núcleo publicitário seriam responsáveis por peculato em relação ao Banco do Brasil, em função de terem desviado valores que deveriam ser repassados à instituição financeira conforme contrato mantido com as agências publicitárias. Neste caso, ainda foi acusado Henrique Pizzolato, diretor de Marketing do Banco do Brasil, que também teria se valido de mecanismos de lavagem de dinheiro para receber vantagem indevida paga pelos publicitários em razão da função pública exercida por Pizzolato - troca de vantagem que caracteriza a prática de corrupção ativa e corrupção passiva.

A análise segue com a votação do capítulo V, pela qual é imputado o crime de gestão fraudulenta à Kátia Rabello, José Roberto Salgado, Vinícius Salgado e Ayanna Tenório, integrantes do comando do Banco Rural, pelos valores ilicitamente concedidos para a operação criminosa, por meio de empréstimos simulados.

Em seguida, é votado o capítulo IV, no qual se sustentam acusações de lavagem de dinheiro por diversas operações. São acusados todos os integrantes do núcleo publicitário, quais sejam, Marcos Valério, Ramon Hollerbach e Cristiano Paz. Também foram incluídos os subordinados Rogério Tolentino, Simone Vasconcelos e Geize Dias, além dos membros do núcleo financeiro, mencionados supra.

O capítulo VI passa a apreciar (i) prática de corrupção ativa por José Dirceu, Delúbio Soares, Marcos Valério, Cristiano Paz, Ramon Hollerbach, Simone Vasconcelos, Geize Dias, José Genoíno, Rogério Tolentino e Anderson Adauto, em função da compra de apoio de parlamentares membros do Partido Liberal, Partido Progressista, Partido Trabalhista Brasileiro e Partido do Movimento Democrático Brasileiro; e (ii) alguns dos parlamentares destes partidos, por sua vez, são acusados de corrupção passiva, pelo recebimento da vantagem indevida.

Aos seguintes parlamentares ainda foram acrescidas as acusações de lavagem de dinheiro e formação de quadrilha: (i) Valdemar Costa Neto, do Partido Liberal, com auxílio de Jacinto Lamas; (ii) Pedro Henry, Pedro Corrêa e José Janene (que veio a 
falecer), do Partido Progressista, com auxílio de João Cláudio Genu, Enivaldo Quadrado e Breno Fischberg. Neste contexto, os réus dos núcleos publicitário, financeiro e político, no capítulo II, são acusados pelo crime de formação de quadrilha.

\subsection{A estrutura do delito de dever}

Uma primeira evidência disso é a ausência de ponderação dos tipos de peculato e corrupção passiva. A forma como tais tipos são previstos na lei nos indica delitos de infração de dever e, portanto, alheios à conformação de domínio do fato. Vejamos a fórmula dos capita destes artigos:

Art. 312 - Apropriar-se o funcionário público de dinheiro, valor ou qualquer outro bem móvel, público ou particular, de que tem a posse em razão do cargo, ou desviá-lo, em proveito próprio ou alheio: $[\ldots]$

Art. 317 - Solicitar ou receber, para si ou para outrem, direta ou indiretamente, ainda que fora da função ou antes de assumi-la, mas em razão dela, vantagem indevida, ou aceitar promessa de tal vantagem: [...] (BRASIL, 1940).

Tratam-se, pois, de fórmulas que se vinculam a um núcleo específico de deveres. Conforme elaborado por Roxin, temos aqui uma estrutura apartada do domínio, o que implicará consequências relevantes, notadamente (i) a flexibilização ao se verificar a consciência das circunstâncias objetivas; e (ii) o partícipe passa a ser o extraneus, ou seja, aquele que não é titular do dever, mas auxilia o intraneus.

Os ministros não têm como premissa da análise dos tipos no caso concreto a conformação estrutural destes crimes. Isto é, eles não partem de uma ponderação do que sejam estruturalmente delitos de dever, tampouco como os tipos de peculato e corrupção passiva se enquadram nesta formatação. A princípio, esta carência não prejudica como os tipos são concebidos no caso, tendo em vista que os ministros, para considerar configurado o tipo no caso concreto, seguem constatando a presença dos elementos típicos, a saber, ter a responsabilidade e atribuições do cargo de funcionário público. Contudo, a falta de uma sólida compreensão sobre a estrutura de tipos de dever, porém, fragiliza a argumentação do Supremo ao se buscarem as implicações práticas dos crimes. Um importante aspecto prático que resta mal fundamentado é o concurso de agentes no âmbito do peculato. Enquanto um delito de infração de dever, a prática do peculato por mais de um autor está fundamentada na quebra conjunta de dever único atribuído igualmente a todos os autores. Porém, chama a atenção o fato de que esta discussão se faz ausente no voto do Ministro Relator, que se omite em justificar como aqueles que não são funcionários públicos podem responder também por peculato: 
No caso agora em julgamento, os sócios utilizaram a DNA Propaganda para se apropriar dos recursos concernentes aos bônus de volume, violando o contrato firmado com o Banco do Brasil, com a conivência do responsável pela fiscalização, Sr. HENRIQUE PIZZOLATO.

$[\ldots]$

Conclui-se, assim, que CRISTIANO PAZ e RAMON HOLLERBACH participaram da atividade criminosa, consistente no desvio de recursos públicos da ordem de $\mathrm{R} \$$ 2.923.686,16, correspondentes aos bônus de volume pagos à DNA Propaganda por terceiros prestadores de serviços ao Banco do Brasil, com intuito de auferir vantagens financeiras ilícitas em detrimento do Banco do Brasil, nos termos do art. 29 do CP. (BRASIL, 2012, fl. 52.349).

Aliás, a condenação dos particulares junto ao funcionário público parece mais fundamentada num conceito expansivo de autor. Aqui, a fundamentação pelo art. 29 do CPB sugere equiparação das condutas para fins de responsabilização enquanto autores, restando sua distinção somente quanto ao merecimento de pena no campo da culpabilidade. Ausentes, portanto, os esforços para fundamentar a autoria de todos os agentes, tampouco para delimitar um caso de partícipes e autores (extraneus e intraneus, respectivamente).

O Ministro Fux argumenta pela comunicabilidade, ao abordar outra imputação de peculato:
A condição de funcionário público, necessária para a caracterização do crime do art. 312 do Código Penal, é estendida ao $5^{\circ}$ denunciado (Marcos Valério) a partir do $15^{\circ}$ denunciado (João Paulo Cunha), com o qual atuou em conluio, em razão do art. 30 do mesmo diploma, que determina a comunicação das condições de caráter pessoal quando elementares do crime. (BRASIL, 2012, fl. 53.165).

Embora coerente com a previsão legal da comunicação da elementar pessoal, a comunicabilidade não é isenta de críticas numa perspectiva geral da teoria do domínio do fato. Na verdade, ao permitir que o dever de uma pessoa se comunique a outro sujeito, autorizando que o extraneus responda como autor do delito, vai em sentido contrário em relação ao que se entende no conceito restritivo de autor e a ideia de figura central do autor desenvolvida por Roxin.

Em última análise, portanto, a comunicabilidade das circunstâncias se torna um dispositivo contrário à fórmula do domínio do fato. Primeiro, porque se enquadra mais como um pressuposto necessário à visão expansiva de autor, igualando as contribuições no plano da autoria. Segundo, o extraneus pode ser responsabilizado como autor pelo 
delito de infração de dever, contrariando a premissa estrutural de delitos de domínio e delitos de dever. Por fim, o conceito restritivo bem determinado na legislação penal não precisaria de comunicabilidade de circunstâncias para fundamentar a responsabilização daqueles que contribuem com o intraneus no delito de dever, bastando que houvesse a tipificação da participação.

O problema põe-se já no plano da legitimação. Como pode alguém se tornar destinatário de um dever que não é seu? $\mathrm{O}$ agente isento do dever descrito no tipo não pode ser igualado juridicamente ao detentor do dever. [...] Esta nivelação fere algo que não é um mero sentimento de justiça, mas sim o próprio princípio da culpabilidade. No entanto, isso não significa que um extraneus que participa de um delito especial deve permanecer impune [...] A solução mais correta parece ser a de punir o extraneus todavia como partícipe e não como autor. (GRECO; ASSIS, 2014, p. 75-76).

Por fim, os ministros perdem uma oportunidade vantajosa em trabalhar as diferentes estruturas para uma figura central do autor e, assim, os limites do domínio do fato - um primeiro indício de que a teoria é deturpada para uma razão de punibilidade, que possa convir aos resultados buscados pela corte.

\subsection{Crime de quadrilha e domínio de organização}

O domínio por organização ainda é uma espécie amplamente debatida. A questão de um aparato alheio ao direito teve especial significado para confrontar grupos criminosos como máfia e Estados totalitários (notadamente, no contexto em que Roxin aperfeiçoou a teoria, o Estado nazista).

$\mathrm{Na}$ decisão do STF, encontramos diversas referências a aspectos que se assemelham aos do domínio por organização, principalmente quando se busca delimitar a figura de quadrilha. Por isso, especial atenção nos chama como os ministros percebem o tipo de quadrilha e em que medida podemos coordenar esta perspectiva com a potencial compreensão de elementos do domínio de organização.

As dificuldades começam no que diz respeito ao enquadramento do tipo de quadrilha. Isto porque a divergência primária que se instaura entre os ministros é uma divisão simplista sobre o tipo quadrilha ser "mero concurso de agentes" ou "mais do que um concurso de agentes". E esta divergência começa porque os ministros falham ao entender o concurso de agentes enquanto basilar estrutural no exame da prática de delitos.

Ao postular pelo destacamento da quadrilha em relação ao "mero concurso de agentes", o grupo de ministros que se alinham a este entendimento está pensando no concurso como uma situação mais específica. Esta não é definida pelos julgadores, mas 
da qual a priori já se diferencia da quadrilha por determinados elementos, quais sejam, a quantidade de sujeitos que integram o grupo, a estabilidade nas relações de associação entre estes indivíduos e a finalidade para cometimento de crimes. ${ }^{1}$ Nesse posicionamento segue o Ministro Lewandowski, para quem o crime de quadrilha não se confunde com concurso de agentes, mas sim se assemelha a um crime societário, com elevado nível de organização que dificulta a individualização da conduta (BRASIL, 2012, fls. 55.51755.520).

Com efeito, não basta, para a caracterização do delito de quadrilha, a simples coautoria em diversos crimes, de forma continuada ou em concurso material, se não ficar evidenciado que os coautores se associaram, de forma estável e permanente, para o fim de praticá-los.

Portanto, é a indeterminação da prática de crimes na ação final que diferencia a quadrilha do concurso de agentes.

É dizer, não é a prática em coautoria de dois ou mais crimes, que vai caracterizar o bando ou quadrilha. É preciso que haja uma conjunção permanente com um acordo subjetivo de vontades para praticar uma série indeterminada de crimes. (BRASIL, 2012, fls. 55.518).

O problema é que o concurso de agentes por si só abarca um topos mais amplo, de todas as conformações em que reconhecemos estrutural e ontologicamente a prática do delito pela articulação entre mais de um indivíduo, em algum nível de acordo entre eles. $\mathrm{O}$ concurso de agentes se coaduna com o conceito aberto de domínio do fato, a ser verificado de diversas formas. Já o concurso de agentes, como compreendido por aqueles ministros que entendem quadrilha como "mais do que mero concurso de agentes" seria algo como a atuação de autor e partícipes ou, no máximo, a prática pela coautoria. Nessa lógica, ao tipo de quadrilha restaria a conformação, necessariamente, de um domínio de organização. ${ }^{2}$

Como consequência da má conceituação de concurso de agentes, há confusão entre elementos estruturais e elementos normativos. Ao pensar o concurso de agentes como algo mais específico e, assim, o tipo quadrilha como algo além do concurso de agentes, ignora a própria estrutura por trás do crime de quadrilha, ou seja, ignora que a base do tipo não deixa de ser a articulação de mais de um indivíduo. Os elementos utilizados para diferenciar quadrilha não são todos, pois, aspectos que estruturalmente,

\footnotetext{
1 Neste ponto de finalidade, contudo, destacamos que entre os ministros emerge uma divergência. Alguns entendem que deve ser uma associação criminosa para cometimento de diversos crimes não especificados, enquanto outros concordam que podem os indivíduos se associarem para cometer crimes específicos.

2 Os ministros desta posição, inclusive, fazem alusão a características similares àquelas atribuídas ao domínio de organização, conforme analisaremos mais detalhadamente infra.
} 
identificados na própria natureza das coisas e que distinguem este tipo: quadrilha como tipificada em nossa legislação não deixa de ser uma construção normativa, que ainda não pode se sobrepor a sua base estrutural como concurso de agentes. Assim, o processo é identificar que elementos da estrutura foram incorporados normativamente, ou seja, no âmbito das possibilidades de concurso de agentes, que elementos estruturais o legislador entendeu merecedor de tipificação e em que medida, para que pudesse construir o tipo quadrilha. A partir disso que podemos começar a pensar: como pode se conformar o domínio do fato no crime de quadrilha? Como é o concurso de agentes na quadrilha? Portanto, vejamos o tipo de quadrilha no art. 288 do CPB

Art. 288. Associarem-se 3 (três) ou mais pessoas, para o fim específico de cometer crimes: [...] (BRASIL, 1940).

E agora vamos partir para a compreensão dos elementos levantados pelos ministros, especialmente a estabilidade. Não questionamos a estabilidade enquanto um aspecto a ser reconhecido na própria realidade de como os sujeitos podem coordenar suas atividades, mas estaria a estabilidade incorporada pela tipificação de quadrilha? Partindo do pressuposto de que sim, em que medida? Como consequência, devemos entender de que forma esta estabilidade é incorporada enquanto elemento normativo caracterizador do tipo, isto é, como ela foi tipificada enquanto opção do legislador. Destaca-se como o legislador optou por tipificar as condutas praticadas por mais de três colaboradores, o que poderia indicar uma certa condição de estabilidade e associação dos agentes digna de norma penal. ${ }^{3}$

Ressaltamos que, ao explicar o tipo de quadrilha, no acórdão, a exemplo da posição assumida pelo ministro Lewandowski, parece ser feito o raciocínio inverso: parte-se de um conceito de estabilidade, tal como auferido da norma; em seguida, visa-se a buscar esta estabilidade normativa no real, mas como característica intrínseca/natural do que ele entende como "mais do que mero concurso de agentes".

Vejamos, porém, que apenas pela redação legal e pela fundamentação dos ministros desta posição, não é possível fixar a prática de quadrilha a uma manifestação específica de domínio do fato. Não apenas os ministros não tomam as considerações da teoria, como também trazem o elemento diferenciador principal, a estabilidade, em um vazio de conteúdo, sem delimitar propriamente como a estabilidade foi incorporada no tipo, tampouco como ela se verificou no caso concreto.

\footnotetext{
3 Nisso, poderíamos até ir mais longe e promover um exercício mental para procurar identificar algum nível de estabilidade que foi optado pelo legislador ao construir o tipo de quadrilha - até mesmo para que possamos diferenciar quadrilha de outras formas de associação criminosa previstas em nossa legislação penal. Destacamos a referência à organização criminosa, na Lei n. 9.613/98.
} 
Diante disto, entendemos que o tipo quadrilha poderia se compatibilizar tanto com a coautoria funcional quanto com o domínio de organização. Se admitido qualquer conformação de estabilidade, a princípio, portanto, não tem como especificar qual a compatibilidade do tipo quadrilha. A escolha do legislador por criminalizar a associação criminosa de três ou mais indivíduos permite que mesmo aparatos não tão complexos como organizações criminosas totalmente alheias ao direito possam estar contempladas. Ressaltamos aqui que, mesmo se for o caso de uma associação com alguma coordenação e mesmo um chefe, isto não afasta a estrutura possível de coautoria, levando em consideração o aumento de pena na figura do organizador. ${ }^{4}$

A falta em considerar os elementos estruturais e como podem ser considerados incorporados pelo tipo de quadrilha gera confusões e divergências na fundamentação e análise do tipo. Vimos a posição do Ministro Lewandoski em pensar quadrilha como mais do que concurso de agentes. A Ministra Rosa Weber chega mais próximo de pensar quadrilha como domínio de organização, ao entender o elemento de fungibilidade como algo incorporado pelo tipo, mas ainda reconhece uma distinção em relação a grupos considerados mais organizados.

Extremo, pois, há de ser o cuidado para não confundir associação criminosa com mera coautoria. Exige-se certa autonomia do crime de quadrilha em relação aos crimes concretamente praticados. Para tanto, necessária a configuração de uma entidade autônoma, formada pelo vínculo associativo transcendente aos indivíduos que a compõem.

[...]

Elemento característico da existência autônoma da associação é a presença de programa delitivo que persista mesmo diante da substituição dos membros da quadrilha. Assim, se de quadrilha ao feitio legal se trata, o grupo constituído para a prática de roubos, ou delitos de outra natureza, inclusive os denominados crimes do colarinho branco, mantém-se mesmo quando presos ou substituídos alguns de seus membros.

4 Em uma breve ressalva sobre o crime de quadrilha a partir do domínio do fato e as justificativas dos ministros, entendemos que não faz sentido definir quadrilha de forma tão ampla, por duas razões lógicas. Primeira, porque o domínio de organização pressupõe um aparato e estrutura de concurso de agentes muito sofisticado e, por conseguinte, representaria maior ameaça ao bem jurídico paz pública, não fazendo sentido estar situado na mesma margem de punibilidade que uma associação criminosa menos complexa e pautada em coautoria. Segunda porque, em interpretação sistemática com outras leis do sistema penal brasileiro, limitar quadrilha seria determinar uma linha divisória frente a outras tipificações de associação criminosa, v.g. a referência à organização criminosa na Lei n. 9.613/98. 
Certamente não se deve ir ao extremo de exigir, para configuração do crime de quadrilha, a existência de elementos constitutivos formais, como um estatuto. $\mathrm{O}$ usual mesmo é a inexistência de qualquer elemento constitutivo, uma vez que constituiria prova do crime contra os associados.

Também não cabe a postura extrema de exigir, para a definição do crime de quadrilha, uma estrutura complexa, com divisão de tarefas e estatuto fundador, formal ou informal. Quadrilha não se confunde com grupo criminoso organizado e não se resume a associações como a Costa Nostra siciliana ou a Yakuza japonesa. (BRASIL, 2012, fls. 52.891-52.892).

O que seria a proposta da ministra então? Se não é coautoria, mas não chega aos casos modelo de domínio de organização, trata-se de um intermediário? A fundamentação de cada ministro acaba tendo de ser analisada conforme o resultado que é buscado. Para os ministros Lewandowski e Rosa Weber, o entendimento de quadrilha como "mais do que concurso de agentes" basta ao seu entendimento de que o tipo não restou configurado no caso. O Ministro Fux, por outro lado, tendo em vista entender o tipo quadrilha configurado e justificar a prática do crime mesmo por aqueles mais distantes da prática objetiva do tipo, vê na quadrilha o autêntico concurso de pessoas, consubstanciado no domínio funcional do fato (BRASIL, 2012, fls. 57.567-57.571).

\subsection{A análise do crime empresarial}

Outro ponto que preocupa é como se estuda a criminalidade de empresa no acórdão, tendo em vista haver uma confusão entre o aparato criminoso constituído para o propósito de cometer crimes e o uso das constituições da empresa para a finalidade criminosa.

Determinados crimes, notadamente aqui o caso de gestão fraudulenta, se caracterizam pela prática no âmbito empresarial. Mas, novamente, falta preocupação com a estrutura e o domínio num crime empresarial. No julgamento, ao se examinar o cargo ocupado pelo indivíduo na empresa, busca-se apenas pautar sua responsabilização com base em (i) a posição assumida na empresa; e (ii) a subjetividade do que o sujeito conhece ou deve conhecer a respeito do funcionamento da empresa.

Nesse sentido, falta uma compreensão adequada de como se materializa o crime empresarial. A Ministra Rosa Weber, ao apreciar o delito de gestão fraudulenta no capítulo $\mathrm{V}$ da denúncia, traz a primeira consideração equivocada. Segundo a ministra, o domínio do fato pressupõe que se deva identificar quem controla ou tem o domínio. 
Assim, o que se há de verificar, no caso concreto, é quem detinha o poder de controle da organização para o efeito de decidir pela consumação do delito.

$[\ldots]$

Importante salientar que, nesse estreito âmbito da autoria nos crimes empresariais, é possível afirmar que se opera uma presunção relativa de autoria dos dirigentes. Disso resultam duas consequências: a) é viável ao acusado comprovar que inexistia o poder de decisão; b) os subordinados ou auxiliares que aderiram à cadeia causal não sofrem esse juízo que pressupõe uma presunção juris tantum de autoria.

Tais considerações são feitas em função da suscitada - e rechaçada - nulidade da denúncia por não individualizar as condutas dos delitos imputados aos dirigentes à testa da empresa, especialmente do Banco Rural.

Ora, se a vontade do homem de trás, sobre quem recai a presunção de autoria do crime, constitui a própria ação final da ação delituosa da empresa, o que se há de descrever na denúncia é como referida empresa desenvolveu suas ações. Basta isso. A autoria presumida do ato é de seus dirigentes. Isso, como se viu, não se aplica aos auxiliares cujo comportamento em nível de colaboração tem de ser esclarecido na peça inicial do acusador. (BRASIL, 2012, fls. 52.776 e 52.777$)$.

De imediato a ministra pressupõe um domínio de organização - cuja aplicabilidade em contexto empresarial é muito discutida, tendo em vista que a formulação original se destina a aparatos de poder articulados de forma totalmente alheia ao direito, o que não é o caso de uma empresa. Mais problemático é a ministra concluir que de tal domínio decorre uma presunção relativa de autoria.

$\mathrm{Na}$ verdade, opera-se uma confusão entre elementos de um delito especial e domínio de organização, com a produção de uma fórmula avessa a essas duas construções. A princípio, trata-se de controle exercido por um homem de trás como em autoria mediata; contudo, este controle é uma decorrência pressuposta da característica especial do autor enquanto um dirigente de empresa, quase como na estrutura de um dever que, uma vez infringido, está caracterizada a autoria.

Ao final, a ministra não fundamenta o domínio por não verificar como poderia ser dar o controle efetivamente exercido pelo dirigente; tampouco propicia um argumento para o delito especial, na medida em que somente tangencia as consequências da caracterização do autor. Cria-se uma categoria nova e intermediária, alheia à formulação de Roxin e calcada na presunção de responsabilidade. 
Luís Greco e Augusto Assis (2014, p. 81-122) também afastam a tese de que os delitos empresariais se sujeitam ao domínio. Segundo os autores, a formulação original de Roxin não tem como contemplar a empresa, vez que o critério de fungibilidade esteja necessariamente vinculado ao caráter alheio ao direito.

Mais complexa parece a situação diante do requisito da fungibilidade do executor. Fungibilidade e dissociação do direito estão intimamente relacionadas. No modelo original de Roxin, a dissociação do direito decorre da exigência de fungibilidade; apenas em uma organização que está completamente alheia aos comandos da ordem jurídica existiria a pronta substituibilidade de cada executor. (GRECO; ASSIS, 2014, p. 103).

A fungibilidade não tem, pois, como ser estendida a comandos lícitos. Tampouco se sustenta um critério substitutivo à fungibilidade, que resta imprescindível à verificação do domínio de organização.

No geral, com base na ideia de domínio do fato não se responsabiliza o gerente da empresa de modo mais extenso do que já era possível fazer com base na interpretação tradicional e mais natural do art. 29, caput, CP. Em especial, é de frisar-se que a mera detenção de um alto posto em uma estrutura hierárquica não confere domínio do fato ou torna alguém autor daquilo que fazem os inferiores. É o comportamento do gerente, e não a sua posição, que interessa em primeiro lugar ao direito penal. (GRECO; ASSIS, 2014, p. 107).

Não entraremos em detalhes, por não ser objeto específico deste trabalho, mas os autores tomam a análise citada supra como premissa para argumentar pela natureza do crime empresarial como um crime de omissão imprópria. Portanto, um delito especial, sobre o qual não incide a teoria do domínio do fato.

O Ministro Joaquim Barbosa (BRASIL, 2012, fls. 54.179), por outro lado, segue uma linha de coautoria ao somente caracterizar a divisão de tarefas. Além disso, reconhece no concurso de agentes um caráter muito mais instrumental que facilite a denúncia por mitigar a necessidade de individualização de condutas.

O Ministro Lewandowski (BRASIL, 2012, fls. 54.210), porém, vai em outro sentido considerando o tipo de mão própria, mas não chega no mérito deste delito não ser, portanto, um delito de domínio, ao que reformaria as possibilidades de concurso de agentes.

Já o Ministro Fux (BRASIL, 2012, fls. 54.309-54.312) toma como uma das premissas o que ele denomina coautoria funcional, sendo esta não definida pela realização de elementos objetivos do tipo, mas sim pela realização de contribuição necessária e 
indispensável ao perfazimento do injusto penal. Além de ser uma posição que pressupõe ser o delito empresarial um crime de domínio.

A lógica por trás da argumentação dos ministros é fundamentar a responsabilidade dos administradores, independente do quão afastados eles estejam da prática objetiva do tipo penal. Não que este fim seja impossível ou desencorajado pela teoria do domínio do fato, mas a maior preocupação da corte é chegar à punibilidade, sem importar a fundamentação e adequada averiguação da estrutura delitiva.

Por isso, a fundamentação na análise de estrutura do injusto penal é equivocada. Cada julgador busca, a partir de considerações superficiais do domínio do fato, a relação do indivíduo com a prática do delito. O resultado é um esforço argumentativo para se estabelecer esta relação, esforço que, além de desnecessário, se tomadas as premissas corretas, é malsucedido, vez que cada ministro chega a uma conclusão diferente do que seja o delito e a estrutura do injusto.

\section{Conclusões}

Reiteradamente sustentamos haver uma compreensão não esclarecida da prática do injusto penal e do domínio do fato. A razão de fundo para isso está em como os ministros claramente ainda veem no domínio uma questão de culpabilidade e punibilidade. O resultado inevitável é que o "domínio" resta enquanto elemento a se agregar posteriormente à análise do injusto penal e ao entendimento que os julgadores já têm consolidado do injusto.

Esta questão, na maioria das vezes, é uma premissa implicitamente tomada dos julgadores, mas escancarada como conclusão equivocada em determinados excertos do acórdão.

O cerne da responsabilização penal reside na demonstração de sua adesão individual à vontade delitiva dos demais réus, a enquadrá-la, como instrumento partícipe ou coautora. Como visto, o fato de se tratar de empregada e, como tal, de trabalhadora subordinada, e de não dispor de poderes sobre o patrimônio da sociedade empresária não afasta, isoladamente, o domínio do fato delitivo, elemento da culpabilidade, cuja presença deve ser aferida tendo em vista a prova produzida em relação à real natureza de sua participação no ilícito, levando-se em conta o seu conhecimento dos fatos e a unidade de desígnios e vontades com os demais agentes. (BRASIL, 2012, fls. 52.870).

Esta posição ainda se sobressai quando as contradições do raciocínio do Supremo são colocadas em cheque. Afinal, se a apreciação do caso começa num esforço argumentativo de compatibilizar o domínio do fato com previsão do art. 29 do CPB, 
as justificações acabam expondo as falhas de raciocínio: como o domínio do fato é, para a corte, fator de punibilidade e culpabilidade, e não como estudo do injusto penal diferenciando autoria e participação enquanto dimensões da sua estrutura, a captação do delito na verdade dispensaria tal formulação teórica e se bastaria na redação do art. 29, que já é abrangente o suficiente.

Portanto, Sr. Presidente, a solução do caso não reclama grandes construções teóricas, na verdade, à luz do princípio da legalidade, a resposta está no artigo 29 do Código Penal "quem, de qualquer modo, concorre para o crime incide nas penas a este cominadas, na medida de sua culpabilidade". (BRASIL, 2012, fls. 56.772).

Citando excertos de Celso de Mello e Rosa Weber, Alaor Leite (2014) fundamenta como a Suprema Corte procura problematizar a compatibilidade da teoria com o art. 29.

\begin{abstract}
Outro aspecto digno de nota é a consideração, presente em alguns votos, de que a diferença fundamental entre autoria e participação só se revelaria na dosimetria da pena, em outras palavras, que a distinção entre autor e partícipe é uma questão de merecimento de pena. Essa consideração é equivocada caso se parta efetivamente da teoria do domínio do fato, e parece ter sido induzida pela redação do art. 29, caput, $\mathrm{CP}[\ldots]$ A teoria do domínio do fato é, antes de tudo, uma teoria que determina a extensão dos tipos penais. (LEITE, 2014, p. 131-138).
\end{abstract}

Segundo o autor, se o domínio do fato pode exercer algum impacto no nosso sistema penal, é de limitar a responsabilidade e a extensão dos tipos penais, mas não fundamentar merecimento de pena. Então por que adotar o domínio do fato com o art. 29? Ao mesmo tempo que assumem que o art. 29 do CPB tenha por incorporado um conceito restritivo de autor, que, contudo, se encontra limitado por não captar os sujeitos afastados da prática do tipo objetivo; os ministros têm a visão de culpabilidade, confiando que o domínio do fato é um elemento que estenda a punibilidade e possa converter o status quo em punibilidade. Porém, mal se apercebem que a visão ampla de punibilidade que buscam está já numa leitura fria do referido artigo, cuja redação se basta para este propósito (LEITE, 2014, p. 132).

Por fim, entendemos ser mais comprometedor como a Corte chega a desenvolver um pensamento de utilidade instrumental da teoria. Nesse sentido, a Ministra Rosa Weber e o Ministro Ayres Britto parecem concordar sobre o elemento facilitador do domínio do fato.

A SENHORA MINISTRA ROSA WEBER - Em função ainda da teoria do domínio do fato. Pelo menos no meu voto, 
pela forma de julgamento segmentado, às vezes as premissas teóricas ficaram um pouco afastadas. O que aconteceu? Inúmeras defesas invocaram a inépcia da denúncia por falta de individualização das condutas. De fato, quando se tratava do núcleo político, havia nome, endereço, telefone, CPF. Havia tudo. Agora, com relação ao núcleo operacional, especificamente ao núcleo societário, não só o Banco Rural, mas ainda com relação às empresas de Marcos Valério, no que dizia respeito a Cristiano Paz e Ramon Hollerbach, às vezes a denúncia não explicitava a conduta imputada a cada um. E, por isso, a teoria do domínio do fato ajudava a argumentação que declarava hígida a denúncia justamente pelo tipo do delito que estava sendo descrito naquela peça. Só esse pequeno registro, porque não enfatizei.

O SENHOR MINISTRO AYRES BRITTO (PRESIDENTE) - Perfeito. (BRASIL, 2012, fls. 56.845).

A tomada das premissas estruturais corretas seria um ótimo de eficiência argumentativa, promovendo uma responsabilização bem fundamentada e consolidando as bases unificadas para futuras análises, sem que todos os argumentos e posições tenham de ser revisitados. Não se trata de impunidade, como os ministros parecem entender, mas sim de exercício bem fundamentado e eficiente da jurisdição criminal e constitucional.

São Paulo, 26 de abril de 2019.

\section{Referências}

BRASIL. Decreto-Lei n. 2.848, de 7 de dezembro de 1940. Código Penal. Brasília, DF, dez. 1940. Disponível em: http://www.planalto.gov.br/ccivil_03/decreto-lei/del2848compilado.htm. Acesso em: 22 abr. 2019.

BRASIL. Supremo Tribunal Federal. Ação Penal 470 - Minas Gerais. Relator: Ministro Joaquim Barbosa, 17 de dezembro de 2012. Brasília, DF: Supremo Tribunal Federal, dez. 2012. Disponível em: ftp://ftp.stf.jus.br/ap470/InteiroTeor_AP470.pdf. Acesso em: jul./ago. 2016.

CALLEGARI, André Luís. Imputação objetiva: lavagem de dinheiro e outros temas de direito penal. Porto Alegre: Livraria do Advogado, 2001.

FELICIANO, Guilherme Guimarães. Autoria e participação delitiva: da teoria do domínio do fato à teoria da imputação objetiva. Revista Magister de Direito Penal e Processual Penal, Porto Alegre, v. 2, n. 10, p. 38-59, fev./mar. 2006.

GÓMEZ BENÍTEZ, José Manual. El dominio del hecho en la autoría: (validez y límites). Anuario de derecho penal y ciencias penales, Madrid, v. 37, n. 1, p. 103-131, enero-abr. 1984. 
GRECO, Luís; ASSIS, Augusto. O que significa a teoria do domínio do fato para a criminalidade de empresa. In: GRECO, Luís; LEITE, Alaor; TEIXEIRA, Adriano; ASSIS, Augusto. Autoria como domínio do fato: estudos introdutórios sobre o concurso de pessoas no direito penal brasileiro. São Paulo: Marcial Pons, 2014. p. 81-122.

JESUS, Damásio Evangelista de. Teoria do domínio do fato no concurso de pessoas. Revista Brasileira de Ciências Criminais, São Paulo, v. 7, n. 27, p. 103-116, jul./set. 1999.

LEITE, Alaor. Domínio do fato, domínio da organização e responsabilidade penal por fatos de terceiros. Os conceitos de autor e partícipe na AP 470 do Supremo Tribunal Federal. In: GRECO, Luís; LEITE, Alaor; TEIXEIRA, Adriano; ASSIS, Augusto. Autoria como domínio do fato: estudos introdutórios sobre o concurso de pessoas no direito penal brasileiro. São Paulo: Marcial Pons, 2014. p. 123-168.

ROXIN, Claus. Autoría y dominio del hecho en derecho penal. 7. ed. Traducción de la séptima edición alemana por Joaquín Cuello Contreras y José Luis Serrano González de Murillo. Madrid: Marcial Pons, 2000. 